\title{
Bolon and Lobo: Revealing The Stack Construction on Batak Simalungun and Kulawi Traditional House
}

\author{
Yusfan Adeputera Yusran and Noviani Suryasari
}

\begin{abstract}
It has long been known, the ancestors of the Indonesian have quite advanced knowledge of building technology in its day. Knowledge of the use of natural materials, as well as efforts to combine these materials into structural and construction systems still can be encountered met standing sturdy in custom houses. Among the diversity of form of construction that was built by different tribes, on the different geographical sites, identified several similarities which indicate a common thread between traditional houses scattered in archipelago to the Asia Pacific region and even Europe. This study offers another perspective of common observations about a custom house. Identification on the similarities of construction leads us to an understanding of the phenomenon of the spread of knowledge which occur or other possibilities that brings us to the understanding of how appropriate architecture for archipelago (Nusantara) conditions.
\end{abstract} lobo.

Index Terms-Bolon, custom house construction, genius loci,

\section{INTRODUCTION}

Initially, this research is based on empirical observations of the Batak tribe and its spreading. Actually Batak tribe itself has various derivative sub tribes, consists of: Batak Toba, Karo, Pakpak, Simalungun, Angkola, and Mandailing. Some references say that the ancestors of the tribe of Batak came from Tamils in India. There is also a reference said it is endemic tribes from mainland called Tapian Nauli. It is caused due to mountainous geographical conditions. However among the difference contained in these tribes, it can still identified some similarities include: traditional house forms, symbols, ornaments, linguistics and so forth. The traditional house of Batak by function can be divided into two; house family dwellings called Bolon, and barns called Sopo. Bolon means big, so Bolon house means the big house. On this research, would specify the search to the Bolon of Batak Simalungun.

In the other hand, in the other part of Indonesia, identified some construction which is similar to the Bolon of Simalungun construction. Therefore to support this understanding, the authors use another comparison that shows similarities with the Bolon of Simalungun in order to revail why it is happen and what should we do afterward with this study.

From field observations, identified Lobo, a Kulawi's

Manuscript received August 20, 2014; revised December 12, 2014

Yusfan Adeputera Yusran is with Institue of History of Art and Building Archeology and Restoration, Technische Universität, Wien 1030, Austria (e-mail: yyusfan@yahoo.ca).

Noviani Suryasari is with the Department of Architecture, Brawijaya University, Malang 65145, Indonesia (e-mail: aninoviani@yahoo.com). custom house in Central Celebes, called lobo, have a similarity on its construction with the bolon of Simalungun. This pairing is expected to show that this similarity is not merely limited in physically ways, but is also expected to open up another veil of knowledge related to these similarities, like how the pattern of people distribution at that time as to how this knowledge could be a mental map of building in the archipelago. Methodically, this allows the result of mixing internally and externally. At least, this research helps us identify more about the process of constructing knowledge for later sought the principles to be used in recent times.

\section{Methodology}

Koentjaraningrat (1981), an anthropologist once wrote, "who can explain exactly the existence of a tribe is the tribe themselves, not others". The opinion is true. However, sometimes wrong. third parties opinions needed in making an assessment so that the results could be objective. The basis of this reason that gave rise to the existence of etic and emic view in historical observations, especially in the field of anthropology. In order to get more sophisticated view through the insider and the outsider ${ }^{1}$ [1]. However, due to limitations of time and location reasons, this research use a role as the outsider with an interpretive paradigm in studying these observations ${ }^{2}$ [2].

Through this description, this study try to highlight an etic perspective in a closer way about Batak traditional house particularly Batak Simalungun. This observation based on interest of the construction of the Bolon, and how they symbolize their life by the ornamentation and the decoration as well as its implementation in the house as a whole. In advance, this study also will be compared with some of custom house in Celebes (Sulawesi) due to identified some sameness in the construction of the house as shown in Fig. 1. This conversation will be arrived by juxtaposing all of results description. In this angle, will be pointed out by Attoe's way as a path to describe this phenomenon critically. Interpretive

\footnotetext{
${ }^{1}$ The neologisms 'emic' and 'etic' derive from analogy with the terms 'phonemic' and 'phonetic.' They were coined by the American linguistic anthropologist Kenneth Pike (1954), who suggested that there are two approaches to study of a society's cultural system, just as there are two approaches to the study of a language's sound system. In both cases, the analyst can take the point of view of either the insider or the outsider.

${ }^{2}$ Interpretive paradigm arrived in educational research during the late 1970 s, influenced strongly by anthropology which aims to understand other cultures, from the inside. That is, to understand the culturally different 'other' by learning to 'stand in their shoes', 'look through their eyes' and 'feel their pleasure or pain'.
} 
way that suggested by Attoe [3] allows us to make a plausibility in order to make similar feelings with others. Furthermore, criticism view used to build a new paradigm so that not only involves as a description of research object, but also can touch other aspects of the phenomenon behind this similarity. Therefore, the word of 'reveal' chosen in order to make (previously unknown or secret information) known to others (oxford dictionary).

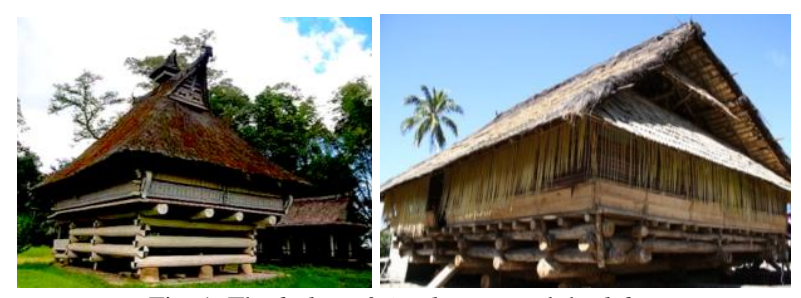

Fig. 1. The bolon of simalungun and the lobo.

This is based on typological thoughts and actions that presuppose two things: first, to recognize and discover basic types; secondly the ability to see things in complementary relationships [4]. This way of looking might in fact be instrumental in the creation of more appreciative, grateful and sensible way of seeing differences by putting them in a continuum and recognizing the invisible connections between them, not only within the architectural discourse but also in all aspects of life in general ${ }^{3}$. In addition, this study also make some possibilities in making acculturation between object study. The study of acculturation in the present gave an opportunity to see how people had changed and thus, also make some possibilities to create a path of how people can use this study in present day [5].

\section{LITERATURE REVIEW}

\section{A. The Bolon of Simalungun}

Bolon Simalungun [6] is basically similar to the Bolon Toba, because the area is located between the settlements of the Batak Toba and the Batak Karo. Geographically, most Batak Simalungun dwells in Deli Serdang, eastern part of Toba lake. Its lead to some similarity identified among them. The house is also pile-dwelling type with a uniqueness in the arrangement of beams which is stacked cross horizontally as shown in Fig. 2. The beams rested on a stone pedestals. House walls slightly angled and has openings/windows. The roof has steep slope with the shape of the shield on the bottom side, while the top side with a saddle-shaped sloping and gevel facing down. At the top end of gevel usually decorated with buffalo heads. In the walls, usually carved, painted and drawn in red, white and black. Besides loaded with philosophical value, decorative ornamentation in the house has the advantage of combining elements of human nature and geometric elements.

Batak Simalungun society believes in the power of spirits. To reject evil so as not to disturb residents, Bolon also realized and decorated with a certain shape. This demon

${ }^{3}$ As Unger suggests, "thinking of manifold possibilities corresponds to thinking in morphological transformations of things and states, be they the material of nature or culture" (Unger in Güney, 2007). repellent decoration can be a human head and tapered shapes. Another traditional ornate is painting on a typical cross section of the horizontal beams under the house. Cylindrical beams only positioned two module on the front of the house. On the back was replaced masts vertical position. House plan extends to the rear with three module structure on the front and 5 to 7 modules to the rear. Two doors are located on the front and rear with odd number stairs. One module structure in the front is not walled and used as a porch. The central part of Bolon Raja also removed and replaced with the main staircase to the house. Thus formed terraces totaling two and are on either side of the main staircase.

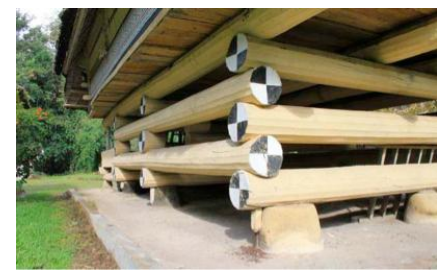

Fig. 2. Construction of Balai Bolon.

The traditional architecture of the Batak Simalungun can still be learned from the four types of buildings that still exist in Huta Pematang Purba as shown in Fig. 3. Purba kingdom stood in the 15th century and the last headed by Tuan Mogang (1933-1947). In this complex still found Balai Buttu (gate house), Bolon Adat (house of the king), Balai Bolon Adat (conference hall and the courts), and Jambur (warehouse) $^{4}$.

Bolon Adat/Raja (house of the king) is divided into two parts, first in the front built in vertical columns, while the small arranged in stacked horizontal beams, the entrance on the east side flanked by upper and lower balcony, sustains at the junction of the roof to the front of the building. Unlike other buildings, this building has double floor with an aisle which declined to center on the lower floor. Lower floor was $2.80 \mathrm{~m}$ from the ground and the aisle hung with rattan to two wooden in the center. Furnace constructed from wood combustion and filled with soil. At the top of the furnace there is a swing which is installed cooking equipment and smoked foods.

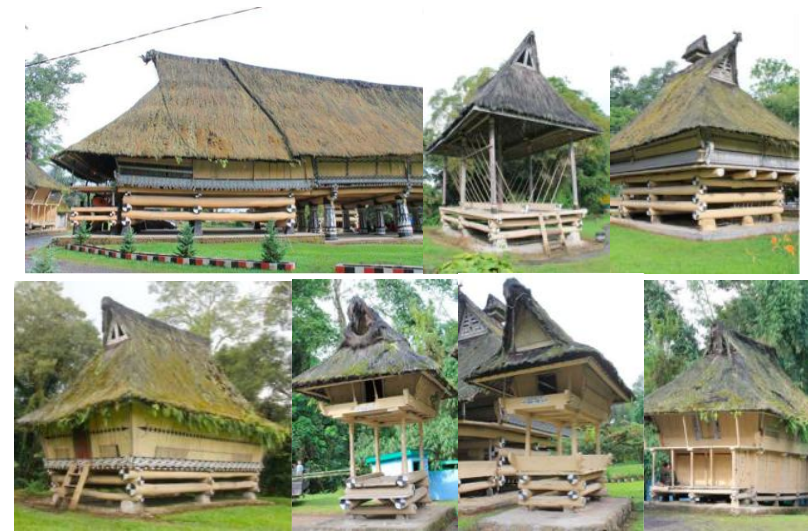

Fig. 3. Complex of the Purba kingdom in Pematang Purba.

In Bolon Adat structure consists of poles with diameter 40

${ }^{4}$ For detail information about Bolon Simalungun in Pematang Purba please visit: https://www.youtube.com/watch?v=rw020JSO8pg 
to $50 \mathrm{~cm}$. Most are round pieces beams and pillars were cut from the forest. The wood used is generally hardwood, timber barges and sometimes bamboo and tied with rattan or split bamboo. The structure is arranged on some big river rocks. The most important pillar of the central chapels carved from thick hardwood. No nails are used in construction, only pegs and fibers wedge rope (sentung).

Balai Bolon was originally used for meetings and to discuss important issues in customary law. The construction almost similar with Balai Buttu, but on a larger scale. The main difference is in the structure of the roof pillars are placed on top of the floor beams. Supported by a pole diameter of $35 \mathrm{~cm}$. The basis of this pole is very important and is covered with carvings, paintings and writings related to customary law. The front (east) is a door, width $80 \mathrm{~cm}$ and height of $1.5 \mathrm{~m}$, surrounded by carvings, paintings and writings with two lion heads on the doorstep. Balai Buttu reached by wooden stairs, the extent of approximately $6 \mathrm{~m} 2$ and $6 \mathrm{~m}$ high. The base consists of horizontal beams which is constructed in square form, stacking four layers on top of a rock.

\section{B. The Lobo of Kulawi}

Lobo [7] as shown in Fig. 4 is a custom building which is closely related to culture and was once the center of custom affairs, government and culture. Lobo serves to accommodate all the activities related to the public interest, especially for the holders of the reins of government (Maradika), the Totua Ngata (the elder), custom board members and community leaders.

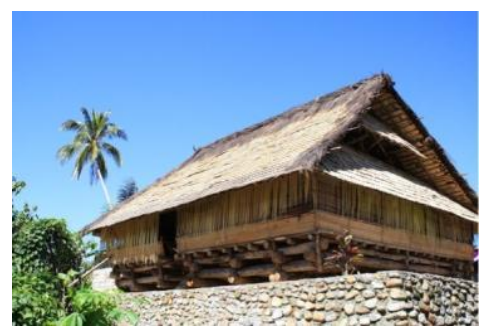

Fig. 4. Lobo in Ngata Toro.

Deliberation, formulation, and policy decisions concerning the interests of the public conducted in this building. Lobo also has a function as a courthouse, where if someone is violating customary law, then he will be tried and tortured inside the lobo. Related with the ceremony, the lobo also serves as a venue of custom ceremonies. This ceremony is usually marked by a procession of buffalo slaughtering.

The space in lobo arranged in accordance with versatile functions. Vertically divided into three parts, the lower part of the building at the center position intended for the general public or the listener sits, and places to eat and drink set, this place is called Padence. On the top edge of padence, there is small round stage that relate directly to the wall called Palangka that are intended for the nobles and Totua Ngata. parallel to the wide side of palangka there is a small kitchen called puavhua.

As shown in Fig. 5, Lobo construction is an arrangement of round timber (bolanoa), which is based on paravatu (stone pedestals), each having a different diameter. The greatest of bolanoa have diameter of $30-40 \mathrm{~cm}$ and the smallest have diameter of $10-15 \mathrm{~cm}$. This bolanoa stacked transverse and oppress each other. The arrangement is a pattern of overall balance. At every joining there is a notch connection and reinforced by rattan rope. In olden lobo, bolanoa arrangement aided by the continuous poles into the ground on the outer side of the lobo and also as part of the wall. Overall construction in strengthening its structure using rattan ropes. Uniquely rattan knot tied to any construction joints required ridden counter-clockwise. It is said that this is the epitome of strength.

Construction materials of floor and wall are generally wooden board. Wall (hungkeke) is not fully closed meant to optimize air circulation inside. In addition, other special purpose for Totua Ngata and nobles who sat in kanavari, who has a habit of chewing areca nut and betel, can utilize it to spit out. In the middle of Dalika, there is a main pole to the roof called Tuha Tongo (king pole). At this pole also decorated with rattan rope called takole. This rattan rope used during traditional ceremonies to bind neck of slaughtered buffalo at the lobo. In connection with that, stairs made without cavities to make easier and able to withstand the load of buffalo into lobo. Made from wood intact and notched five or seven trap (in accordance with the level of society).

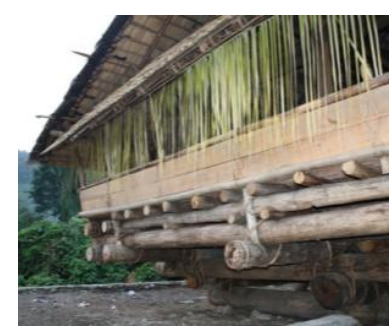

Fig. 5. Construction of Lobo.

Wood on all parts of lobo except the roof, taken from the type of wood called Kole. This local wood is known for its durability. Lobo's roof coverings is a shingle from small and thin boards, usually uses alipaa and kaha wood. These two types of wood are specialists for roof coverings of lobo, known for its resistance to rain water. At the end of the pitched roof using fibers, called kangkuba. Lobo has two ladders (tuka) according to the local belief that one of them functioned as the entrance for spirits ${ }^{5}$.

\section{RESUlTS AND DiscUSSION}

Traditional buildings in Southeast Asia, as it uses local materials in the vicinity, tend to have a common character, these buildings are all built using a variety of bonding techniques and connections, sometimes reinforced with pegs or clamps. In Indonesia, tie and peg applications are widely applied in traditional buildings by means of Mortice, which insert wood projection (a tenon) into the hole made in another timber. This kind joining system applied in Bolon Toba [8].

If viewed from structural studies, the main column of Bolon Toba, Simalungun and Lobo are shoring beams which transverse throughout the house. The walls of the house is

\footnotetext{
${ }^{5}$ For more detail on how To-Kulawi build the lobo, please visit: https://www.youtube.com/watch?v=T8Kzynoo33s
} 
light and stick on the outside, provide additional stability to the entire structure. The wall also supporting the rafters, hung from beams with rattan or notched, while the lower part of the wall attached to the large beams in the floor (such most of typical traditional houses in Indonesia).

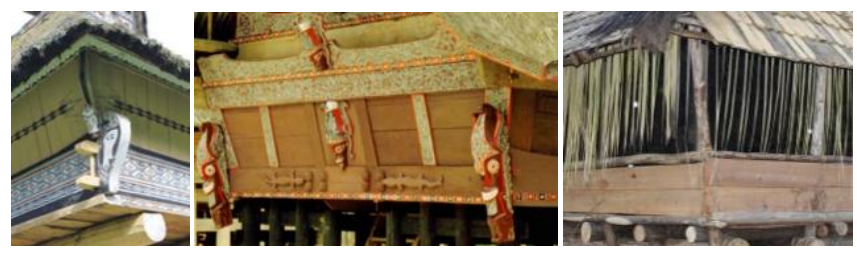

Fig. 6. Walls detail of Bolon Simalungun, Toba and Lobo.

In addition, other similarities identified in wall beams shaped angled outward to form an inclined plane as shown in Fig. 6. This wall aims to avoid enemies and wild animals as well as forming a more versatile space optimal. In Bolon Toba and Simalungun, this wall covering all parts of the wall with a slight opening of the window, while on the wall in lobo is only partially covered.

If viewed Bolon Adat Simalungun, in fact there is a fundamental similarity with the shape of Bolon Toba. From the identification of the Bolon Adat in Pematang Purba there are many similarities with some parts of the Toba and Karo houses. Generally, these similarities were identified from the shape of the body and roof of the house as shown in Fig. 7. Also, identified from the ornamentation and the decoration. Sherwin [9] analyze some style changes that occur when the migration occurs ${ }^{6}$. This change as a result of adapting to a new life in new land.

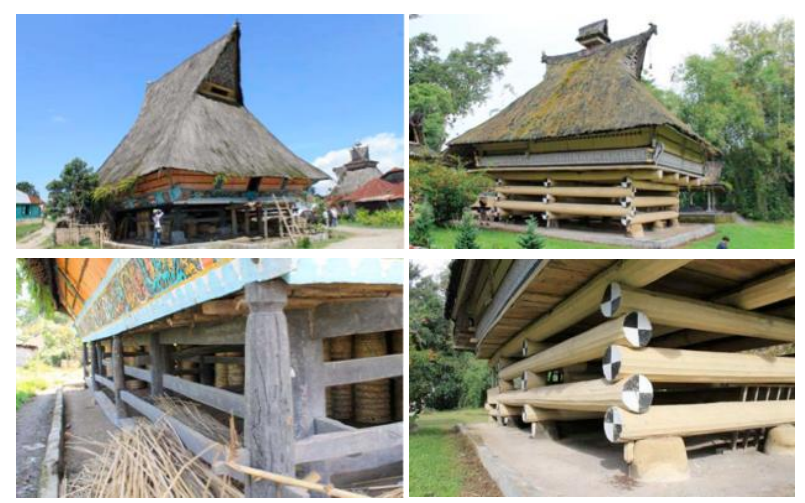

Fig. 7. Comparison of the shape and the structure of Karo and simalungun.

The differences identified in the under structure of the house. The foot of Bolon Toba and Karo has vertical pillars with beams binder. While at Bolon Simalungun use crossed horizontal $\operatorname{logs}$ construction. Before stacking, these logs notched with the intent to provide cradle to the beam on it. There are no ties or hitches in this pile, these structures solely rely on the weight and the notch of the wood.

In almost all cases the posts go up through the living space to support the roof, and the large edge beams to the living area (which give much of the character to the exterior of the

\footnotetext{
${ }^{6}$ Sherwin cited of how acculturated tribe that lived in Negeri Sembilan, in the Malay Peninsula. There, they adapt the style of the Malay roof construction with continuous roof ridge, made from woven palm leaves and fastened on long wooden. This method is much simpler, but produce less stringent arch roof than the original form (gadang house) with a blunt end.
}

building) are supported on cantilevers from the posts. Thus the body of the house seems to float, which adds to the boat like appearance. This system of cantilever edge beams and curtain walls filling in the space between the beams and the roof is probably very ancient as it can be seen in the Toraja areas of Sulawesi.

However, an interesting observation of Bolon in Pematang Purba, it appears there are two different types of pile-dwelling construction as shown in Fig. 8. First, standing on a pile of wooden stack beams and the others stand upright wooden columns. Historically, the initial Bolon house of Simalungun is located on the back (which looks similar to the Batak Karo house with foundation beams stacked) but because the king increasingly had many wives and concubines, then Bolon was extended to provide space and a kitchen for each wives or concubines. It can be seen that the structure of the upright pole is a structure that is applied after pile structure. Another thing that strengthen this notion is the structure of a pile of wooden blocks is also found in other buildings in the complex. It may be that this addition is an effort to broaden the space in a short time. Also, when using stack structure will be constrained by the long dimension of the timber toward space requirements.

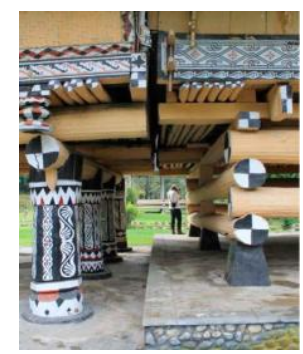

Fig. 8. Dilatation of Bolon Adat in Pematang Purba.

Another case in lobo. In addition be notched, wood construction is stacked and then tied with the rattan. Interestingly, the construction lobo did not use mortice technique and pegs. Fully-way tie with the bonds that must be counter-clockwise bounded. Unlike in the construction of Bolon Simalungun which have been stacked straight from the base to the top of the timber with same diameter of at all (average diameter $25 \mathrm{~cm}$ ), in Lobo, the stack construction enlarged from the bottom to above (such as the inverted triangle). By using such a system requires the lowermost timber should outweigh than the wooden top. The size of the lowermost timber is $30 \mathrm{~cm}$ and respectively tapers upwards.

Another similarity which is shown by these both custom houses in Fig. 9 are use pedestals foundation where wood structures only rely on it as a stepping stone. This foundation has advantages over foundation planted into the ground.

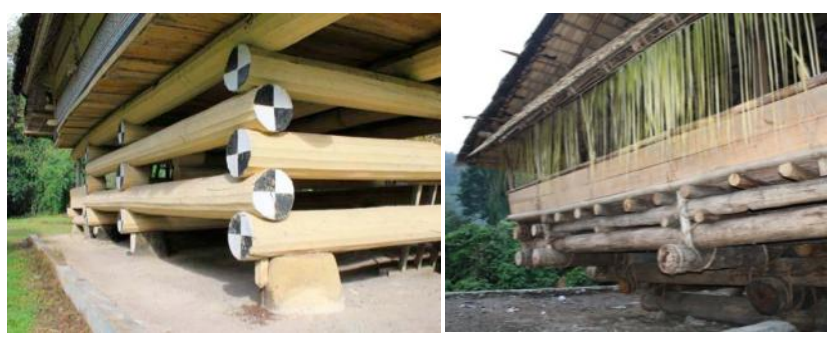

Fig. 9. Comparison of the structure of Balai Bolon simalungun and lobo. 
Indonesia is one of the areas in the world with the most volcanic activity caused by a complex geological history. Therefore probably a more important consideration is that the buildings are made of wood and stand on pedestals is earthquake resistant. This construction is called by Prijotomo [10] as a rocking construction of truss system. This type of construction is very different from construction mostly used by brick building which is rigid and stiff. In essence, rocking construction is a construction that allows the structural elements of the building for moving horizontally to the various ways. When two beams swaying, there will be a time to make two beam interlocked. This locked condition is only temporary, because at the time when the wobble gone, the locking condition also will disappear. This rocking construction was already proven as a reliable construction for earthquake.

On the roof, either bolon toba, simalungun or lobo showed similarity on the roof, all using typical boat overturned-like roof. As for the modification identified in each house still shows a red thread between all of it. The gable of all houses roof use the principles of scooped ridge so at the end of the roof become pointy and decorated with buffalo head or horn. Feature construction derived from this technology also exploited into symbolic effect.

One of the characteristics such as how to connect the beam to the pole. In traditional buildings in most areas of the archipelago such as, Malay, Aceh, Dayak and Bugis, single room units can be easily expanded. This expansion space formed by adding the number of units equal to the different angles, the floor beams of the additional unit is combined with the main pillars in the house. Thus if a pole supporting more than one beam, the beams should be stacked one on top of another, resulting different floor heights. However, the level arrangement is not a common characteristic of these buildings. Strict rules on the floor where the highs and lows are also set, and important space always at the highest floor. Thus, in addition to the technology, we also found a pattern of symbolic meaning of this structure arrangement.

This proves that form the archipelago architecture is the result of a craftsmanship process. In this case, the important role of tools and skills of builders are the main key. With industries influences, the craftsmanship forms are being abandoned for lengthily process reasons. In fact, through this process, at least foster a devotion of what is being done because it is based on sense of mutual cooperation (participatory) and build knowledge process can be transmitted to future generations as well as opening new creative on how to build innovative (allowing the creation of a new form).

If viewed from verticalism aspects, as well as other traditional houses in the archipelago, Bolon and Lobo is also interpreted as a symbol of micro cosmos which representing macro cosmos and divided into 3 parts (tripartite symbolism), the house pedestal as underworld, the body as earthly world, and the roof manifested as heaven. Almost similar pattern is also found in religious buildings such as the temple which symbolizing mountain as the place of the gods or heaven [11].

In addition, other benefits of the ways to build without nails is that these buildings can be dismantled and moved to a new location. A stacked buildings can even be carried/removed from its stone foundation to be brought to a new location. This illustrates that the phenomenon of mutual cooperation are indeed a characteristic in building houses in the archipelago. Mutual cooperation, which at present often formalized as a participatory process, had already be flowing blood of the ancestor in the archipelago. This is clearly illustrated in the previous description of how the Batak build their Huta and how Kulawi people build their lobo. Unfortunately, this process has been very rare met today because of shift of individualistic norms in life increasingly.

Based on the above observations, it can be hypothesized that the association of Bolon and Lobo do exist. This is strengthen by the study of the formation of continents. As we all know that the archipelago was originally formed by two continental fragments, Sundaland and Sahul exposure. In addition, there are several studies that illustrate the possibility of a building knowledge exchange [12], that is:

1) From Geolinguistik terms, this region is considered as the land of origin of the tribes of the Austronesian language user. This opinion is quite reasonable because Gorys Keraf (1991) has stated hypothesis with respect to sea-level rise that inundated the country of origin speakers. According to the origin of Austronesian people it is in the western part of Indonesia, on land which had been sunk. Presumably myths, legends, and fairy tales of the past in the archipelago is not merely a narrative description of the sacred story or solace, because it also may store content on it the truth about ancient events in the past that influenced the development of the local civilization.

2) From Geocultural terms, this region is an area of strategic trajectory in human migrations and cultures of Southeast Asia to the region of Melanesia, Micronesia, and Oceania. Furthermore, this possibility arises because when inhabit a place, other than food, people need a place to stay. Well, this knowledge acculturation emerged as the effect of seeing the potential of new areas and mixed with memories of built his house earlier in his hometown ${ }^{7}$. This such acculturation cause a common thread of a connection between the indigenous architecture of the region form the archipelago up to the Asia Pacific ${ }^{8}$. Lewcock [13] identifies generative concepts in vernacular architecture are among others: the hearth, the courtyard, and the anthropomorphic analogy, that are likely to persist although tradition do change through new technology. Innovation and precedent are always dynamically combined which causes continuous changes in architecture, yet the underlying generative concept remain the same.

\footnotetext{
${ }^{7}$ The philosopher Heidegger is the one who initially introduced the concept of building and dwelling as an intimately bound up mode of thinking. The activity of building and dwelling is being related through people's involvement with the place in the attempt to make sense of a place (Hanan, 2011).

${ }^{8}$ This study also based on Sato's study about the similarity of the houses spread in the pacific region, To Dwell In The Granary The Origin Of The Pile-Dwellings In The Pacific accessed through http://www.sumai.org/asia/refer/sem9102.htm
} 


\section{CONCLUSION}

The relationship between Bolon and lobo, requires more deeper study. For a while, this relationship relates to the possible influence of the diaspora of Batak to the Sulawesi land or vice versa. If viewed the future development of both architecture, it is clear that each develop their own technology.

Interesting if we draw a line in common custom houses in the archipelago. Koji sato even describe that this study gives a clear picture of the beginning of humans live in pile-dwelling houses, that is from the granary (rice barns). In the beginning people might reside on the granary with their grain, but in the course of time, this structure come to be used for the proper residence and has developed its varieties of style, so far as to adapt itself to the ground floor residence.

However, it should also be a concern that the Central Sulawesi is one of the regions in Indonesia which has the highest number of tribes. Recorded 22 tribes are there. Megalithic relics at there also became an attractive material to be studied separately. Palindo statues scattered across the valley of Bada is mute evidence of the development of culture in this place at that time took place rapidly. The statues become one of the mysteries of the world besides megalithic Moai statues on Easter Island and Stonehenge in Wiltshire.

Ironic when we are more concerned on modernity but on the other hand, we keep our own identity labeled and packed as ancient/archaic architecture. We better take our traditional architecture mummificated or more naive, relabel it as vernacular or even sustainable.

This review opens our eyes to see the importance of custom house architecture no longer in the anthro-etnology study ${ }^{9}$. However, with opens our insight about nusantara, scientific view of architectural studies can be freely grown rapidly. As though to a source of water that will never run out. Thus, traditional architecture can be developed also by modifying and transforming into another form. At least this is also the case when the neoclassic style is growing rapidly in the Middle Ages. But the difference, classical developments in the western world do not preserve their nation architecture, but ignored, even killed.

Nusantara architecture is no longer the other architectures, the hick, or the obsolete, but became a new field to embed claim to future generations that once upon a time, our ancestors had created great architecture, calculating, strong against earthquakes, and can last up to hundreds of years. This opportunity should utilized for us to learn to apply the principle to the present. Not instead using concrete bricks which may harm us, and replace the cover with tin roofs that make the house more heat. Furthermore, it extents possibility the birth of a new architectural style which rooted in our own

\footnotetext{
${ }^{9}$ As other European explorers (UK, Belgium, France, Germany) which puts the ins and outs of building and wood architecture of its colonies in culture knowledge. This such knowledge was recorded with a note in a detailed documentation and 'scientific' of a society in a particular space and time. This knowledge is not too ambitious to be predictive, but rather descriptive. Thus, this gives the designation of cultural knowledge, traditioneele architectuur, to the whole local architecture in archipelago. (Prijotomo, Mengusik Alam Pikiran Arsitektur Eropa-Amerika - Merintis Alam Pikiran Arsitektur Nusantara)
}

culture.

\section{REFERENCES}

[1] J. W. Lett, Study Guide and Supplemental Readings for Cultural Anthropology Linguistics 2013 Edition. [Online]. Available: http://jlett-irsc.weebly.com/uploads/2/3/1/8/23188872/study_guide_a nd_supplemental_readings_for_cultural_anthropology__ linguistics_ 2013_edition.pdf.

[2] P. C. Taylor and M. N. D. Medina. Educational Research Paradigms: From Positivism to multipaRadigmatic. [Online]. Available: http://www.meaningcentered.org/journal/volume-01/educational-resea rch-paradigms-from-positivism-to-multiparadigmatic.

[3] W. Attoe, Architectural and Critical Imagination, John Wiley \& Sons, 1978, p. 49.

[4] Y. D. Güney. Type and Typology in Architectural Discourse. [Online]. Available: http://www. fbe.balikesir.edu.tr/dergi/20071/BAUFBE2007-1-1.pdf, 2007.

[5] G. W. Locher, Transformation and Tradition, The Hague, p. 102, 1978.

[6] Building Research Institute, Traditional Buildings of Indonesia Vol. III Batak Simalungun and Batak Mandailing, Ministry of Public Work and Electrical Power, pp. 7-12, 1973.

[7] M. Masyuhada, Arsitektur Kuno di Sulteng: Lobo dan Tambi, Seksi Penerbitan Yayasan Kebudayaan Sulawesi Tengah, 1978.

[8] Building Research Institute, Traditional Buildings of Indonesia, Ministry of Public Work and Electrical Power, pp. 5-8, 1973.

[9] Y. D. Ekaputra and R. Tinggal. Pengejawantahan Teknologi Dan Simbolisme Arsitektur. [Online]. Available: http://www. jurnal.unpand.ac.id/index.php/dinsain/article/view/63.

[10] J. Prijotomo, "Dasar dan wawasan arsitektur nusantara dalam struktur bangunan," presented as keynote speech at Kearifan Lokal dalam Perkembangan Struktur Bangunan Workshop of Department of Architecture Sebelas Maret State University, Surakarta, 2011.

[11] E. Lehner, "Towards a documentation project on javanese candis," in Insular Diversity: Architecture - Culture - Identity in Indonesia, Lehner, Erich, I. Doubrawa, Ikaputra, Eds. Vienna, IVA-ICRA and Dept. of Architecture UGM, p. 25, 2013.

[12] H. M. Ambary, Menemukan Peradaban: Jejak Arkeologis dan Historis Islam Indonesia, Editor Jajat Burhanuddin. Penerbit Logos, p. 150, 1998.

[13] H. Hanan. (2011). A House is a Figure between the Earth and the Sky Case Study: Batak Toba House in Samosir Island. [Online]. Available: http://ruas.ub.ac.id/index.php/ruas/article/view/101.

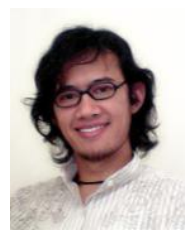

Yusfan Adeputera Yusran is a $\mathrm{PhD}$ candidate at the Institute of History of Art and Building Archeology and Restoration at the Technische Universität Wien Austria.

$\mathrm{He}$ is a lecturer in the Department of Architecture Brawijaya University where he teaches the development of traditional architecture of Indonesia (Nusantara). His research interests include sustainability principles of Nusantara architecture and its integration in modern architectural design. $\mathrm{He}$ is active in international conferences and forum to introduce Nusantara architecture to the world. He has publications in several journals and the latest journal is about implementation of gaba-gaba as acoustic material.

Until now, Yusfan is a member of International Network for Traditional Building, Architecture and Urbanism (INTBAU) and Architecture, Culture and Spirituality Forum (ACS). He was a trainee of Ando Program to Learn Japanese Architecture and also involved in Housing Research Laboratory of Daiwa House Industry.

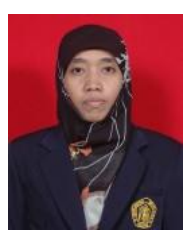

Noviani Suryasari is a lecturer in the Department of Architecture Brawijaya University where she teaches the theory and history of architecture. Her research interests focus on the building conservation and local wisdom in architecture. She has activities in Architectural Reasearch Program and is involved in Ikatan Peneliti Lingkungan Binaan Indonesia (IPLBI). 